\title{
Faktor Geografis dan Konsepsi Peran Nasional sebagai Sumber Politik Luar Negeri Indonesia
}

\section{Agus Haryanto}

Jurusan Hubungan Internasional, Fakultas IImu Sosial dan Politik

Universitas Jenderal Soedirman

Jl. HR. Boenyamin 708 Purwokerto 53122

Agushari.oke@gmail.com

Submitted: 26 August 2015, Accepted: 12 October 2015

\begin{abstract}
This paper discusses the geographical factor as the source of the national role conception and foreign policy of a country. Indonesia has realized his strategic geographic location that laid between two oceans and two continents since the early days of independence. Indonesia is also aware of the geographical features as an archipelagic state. Its raises awareness of Indonesia to keep his territory for the declaration of Djuanda. This paper explore the Indonesian foreign policy that still using geographical factor as a source of foreign policy. This can be seen from the efforts of Indonesia continues to participate in various regional issues that could potentially interfere the sovereignty of Indonesia such as the disputed South China Sea and East China Sea. Indonesia also seeks active in border diplomacy to ensure the sovereignty of its territory.

Keywords: Indonesia, Foreign Policy, National role conception, and Djuanda Declaration
\end{abstract}

\begin{abstract}
Abstrak
Artikel ini mendiskusikan faktor geografis sebagai sumber dari konsep peranan nasional dan kebijakan luar negeri dari suatu negara. Indonesia telah menyadari posisi strategis dari letak geografinya yang berada di antara dua benua dan dua samudra bahkan sejak awal kemerdekaannya. Hal tersebut semakin meningkatkan kesadaran Indonesia untuk (mencetuskan) Deklarasi Djuanda. Artikel ini mengeksplorasi kebijakan luar Negeri Indonesia yang masih menggunakan faktor geografis sebagai sumber dalam pembuatan kebijakan. Dapat dilihat dari usaha Indonesia yang secara kontinyu untuk berpartisi dalam berbagai isu-isu regional yang berpotensi mengganggu kedaulatan Indonesia, misalnya isu perselisihan di Laut China Selatan dan Laut Timur China. Indonesia pun gencar melakukan diplomasi perbatasan untuk mempertahankan territorialnya.

Kata kunci: indonesia, kebijakan luar negeri, konsepsi peran nasional, Deklarasi Djuanda
\end{abstract}

\section{PENDAHULUAN}

Indonesia adalah negara kepulauan (Archipelagic State) terbesar di dunia yang terdiri dari 17.499 pulau dan terletak pada posisi silang dunia, yaitu diantara dua samudera dan dua benua. Dengan dua pertiga luas wilayah yurisdiksi berupa perairan yang luasnya mencapai 5,8 juta $\mathrm{km}^{2}$ dan panjang garis pantai yang mencapai $\pm 81.000 \mathrm{~km}$. Fakta ini menjadikan negara Indonesia sebagai negara yang memiliki sumber kekayaan alam yang berlimpah dan sangat bermanfaat bagi kelangsungan hidup bangsa. Namun demikian, wilayah perairan yang luas, daratan yang melebar dan luasnya wilayah udara di atasnya, menyebabkan wilayah Indonesia sangat rawan terhadap berbagai ancaman serta rawan terhadap infiltrasi asing

Sifat keterbukaan wilayah geografi Indonesia diatas banyakdimanfaatkan oleh pihak asing, misalnya, ditemukannya enam kapal perang milik tentara AS di perairan Natuna pada Juni 2009. Kemudian juga merujuk tulisan dari Kahin dan Audrey (1997) yangmenyebutkan bahwa keterlibatan pihak asing 
dalam konflik internal yang terjadi di Indonesia, banyak memanfaatkan wilayah laut sebagai pintu masuk ke daerah konflik. Indonesia memiliki pengalaman buruk berkaitan dengan keterlibatan pihak asing di dalam konflik internal. Salah satu pengalaman tersebut adalahketerlibatan AS pada pemberontakan daerah PRRI di Sumatera.

Meskipun demikian, penelitian yang berkaitan dengan letak dan struktur geografis Indonesia yang merupakan negara kepulauansebagai sumber politik luar negerikembali mendapatkan perhatian yang cukup besar di era pemerintahan Joko Widodo. Joko Widodo sejak awal pemerintahan menggaungkan slogan Indonesia sebagai Poros Maritim Dunia.Dalam persentasinya di APEC November 2014, Presiden Jokowi mempresentasikan bagaimana pemerintahannya melihat laut sebagai potensi. Indonesia bertekad menjadi Poros Maritim Dunia dengan lima pilar yaitu membangun budaya maritim, mengelola potensi sumber daya laut, mengembangkan infrastruktur untuk konektivitas maritim, melakukan kerja sama dalam bidang maritim, dan membangun kekuatan pertahanan maritim.

\section{KERANGKA PEMIKIRAN}

Berdasarkan kenyataan di atas, penulis melakukan kajian mengenai status negara kepulauan sebagai sumber politik luar negeri Indonesia. Penelitian ini didesain kualitatif historis. Kualitatif historis adalah pendekatan metodologis yang meletakkan kualitatif maupun pengukuran kuantitatif dan menggunakan dokumen historis atau intepretasi sejarawan untuk menggunakan dan menguji teori (Thies, 2002: 352).Istilah yang digunakan ini bukanlah untuk menggambarkan pendekatan baru dalam studi Hubungan Internasional, tetapi menekankan pada pendekatan metodologis yang sebenarnya selama ini telah menjadi tradisi dalam keilmuan Hubungan Internasional.

Sumber data berupa dokumen, jurnal, dan wawancara. Dokumen yang digunakan adalah buku Sejarah Diplomasi Indonesia dari Masa ke Masa dan dokumen berupa transkrip pidato Presiden maupun
Menteri Luar Negeri. Dalam wawancara penulis melakukan wawancara mendalam dengan diplomat senior yaitu Hasyim Djalal dan Darmansyah Djumala. Kemudian, data tersebut dilengkapi dengan berbagai jurnal yang mengungkapkan penelitian terkait politik luar negeri.

Proses analisis data yang digunakan dalam penelitian ini merujuk pada Thies (2002) adalah sebagai berikut: (1) menyeleksi sumber, (2) menentukan sumber utama (3) menentukan sumber sekunder.Untuk validasi data, penelitian ini menggunakan strategi mentriangulasi (triangulated) sumber - sumber data yang berbeda dengan memeriksa bukti - bukti yang berasal dari sumber tersebut dan menggunakannya untuk membangun justifikasi tema - tema secara koheren.

\section{KONSEPSI PERAN NASIONAL DALAM POLITIK LUAR NEGERI}

Istilah konsepsi peran nasional pada mulanya diungkapkan oleh K.J. Holsti pada tahun 1970 dalam tulisannya yang berjudul "National Role Conceptions in the Study of Foreign Policy”. Istilah ini muncul atas dasar perkembangan penyebutan oleh para pengkaji Hubungan Internasional (HI) terhadap perilaku sebuah negara. Holsti menunjukkan kecenderungan para pengkaji, pada waktu itu yang menyebut negara dengan identitas perilaku negara dalam interaksi internasional.Sebagai contoh ada beberapa negara disebut sebagai negara Blok Barat, Blok Timur, maupun Non Blok. Di dalam blok - blok tersebut pun negara seringkali diklasifikasikan lagi menjadi pemimpin blok, penyeimbang atau sekedar negara pinggiran atau pengikut saja (Holsti, 1970: 233).

Penyebutan peran sebuah negara merupakan bentuk dari sistem internasional yang ada pada saat itu.Hoslti juga menyatakan bahwa penyebutan tersebut mengarah pada karakteristik negara yang disebut.

Holsti kemudian melakukan serangkaian penelitian untuk menganalisis peran apa saja yang dimiliki oleh negara dalam sistem internasional. Dalam penelitian ini, Holsti menyatakan negara dalam berperilaku ditentukan oleh konsepsi peran nasional, status negara 
atau posisi dalam sistem internasional, kemudian tuntutan dan harapan peran dari negara lain.

Secara sederhana, Holsti menggambarkan posisi konsepsi perandalam politik luar negeri dengan gambar1.dimana Holsti menganggap kebijakan sebuah negara merupakan hasil dari konsepsi peran nasional yang dimiliki negara tersebut, digabungkan dengan saran atau nilai - nilai yang seharusnya diadopsi sebuah negara. Para pengambil kebijakan memiliki konsepsi yang bersumber dari lokasi (letak) negara, sumber daya dan kemampuan sosial ekonomi, nilai nilai nasional, ideologi, peran tradisional, opini publik, personality, dan kebutuhan politik. Holsti menganggap pengambil kebijakan memiliki "ego" dalam memuat keputusan berdasarkan konsepsi yang dimiliki. Tetapi, Holsti tidak mengabaikan kemungkinan persepsi itu "bergeser" karena konsepsi tersebut juga dipengaruhi oleh status negara yang dipimpin dan saran atau nilai - nilai yang seharusnya dianut negara tersebut seperti perjanjian internasional, opini masyarakat internasional, pemahaman informal, prinsip - prinsip internasional, dan peraturan umum yang berlaku.

Holsti mengemukakan tujuh belas tipe peran nasional yang merupakan komponen kebijakan luar negeri suatu negara,yaitu: (1) Bastion of Revolution, Liberator (benteng revolusi,pembebas), (2) Regional Leader (pemipin kawasan), (3) Regional

Protector (pelindung kawasan), (4) Active

Independent (bebas aktif), (5) Liberation

Supporter (pendukung pembebasan) (6) Anti-Imperealist agent (agen anti imperalis), (7) Defender of the Faith (perlindungan nilai-nilai), (8) MediatorIntegrator (penegah-pemersatu), (9) Regional - Subsystem Collaborator (penggabung sistem kawasan),

(10) Developer (Pembangun), (11) Bridge (jembatan sekutu setia), (12) Faithful ally (sekutu yang setia),

(13) Independent ( bebas), (14) Example (contoh),

(15) Internal Development (pemeritah dalam negeri),

(16) Isolate (mengisolasi diri) dan (17) Other Role (peran lain) (Holsti 1970, 261-272).
Tabel 1 Konsepsi Peran dan Sumber Konsepsi Peran

\begin{tabular}{|c|c|}
\hline KONSEPSI PERAN & SUMBER \\
\hline $\begin{array}{l}\text { Benteng revolusi, } \\
\text { liberator }\end{array}$ & $\begin{array}{l}\text { Prinsip ideologis; sikap antikolonial; } \\
\text { keinginan akan kesatuan etnis }\end{array}$ \\
\hline $\begin{array}{l}\text { Pemimpin } \\
\text { kawasan }\end{array}$ & $\begin{array}{l}\text { Kemampuan unggul; kedudukan } \\
\text { tradisional di kawasan }\end{array}$ \\
\hline $\begin{array}{l}\text { Pelindung } \\
\text { kawasan }\end{array}$ & $\begin{array}{l}\text { Persepsi ancaman; letak geografis; } \\
\text { kedudukan tradisional; } \\
\text { kebutuhannegara terancam }\end{array}$ \\
\hline Pihak bebas aktif & $\begin{array}{l}\text { Ketakutan bahwa konflik "blok" } \\
\text { akan menyebar, kebutuhan untuk } \\
\text { mengembangkan perdagangan } \\
\text { dengan semua negara; letak } \\
\text { geografis }\end{array}$ \\
\hline $\begin{array}{l}\text { Pendukung } \\
\text { liberator }\end{array}$ & Sikap anti kolonial; prinsip ideologis \\
\hline Agen imperialis & $\begin{array}{l}\text { Persepsi ancaman; sikap anti } \\
\text { kolonial menurut pendapat umum; } \\
\text { prinsip ideologis }\end{array}$ \\
\hline Pembela keyakinan & $\begin{array}{l}\text { Persepsi ancaman; prinsip ideologis; } \\
\text { peran tradisional }\end{array}$ \\
\hline $\begin{array}{l}\text { Mediator - } \\
\text { integrator }\end{array}$ & $\begin{array}{l}\text { Letak geografis; peran tradisional; } \\
\text { komposisi budaya-etnis negara; } \\
\text { ketidakterlibatan secara tradisional } \\
\text { di dalam berbagai konflik }\end{array}$ \\
\hline Kolaborator & Kebutuhan ekonomi; rasa \\
\hline kawasan & $\begin{array}{l}\text { "memiliki" kawasan; tradisi politik- } \\
\text { ideologis; budaya bersama dengan } \\
\text { negara lain; letak kawasan }\end{array}$ \\
\hline Pembangun & $\begin{array}{l}\text { Urusan humaniter; beberapa } \\
\text { konsekuensi "kesenjangan" } \\
\text { pembangunan yang telah } \\
\text { diantisipasi; kemampuan ekonomi } \\
\text { yang unggul }\end{array}$ \\
\hline Jembatan & $\begin{array}{l}\text { Letak geografis; komposisi } \\
\text { multietnis negara }\end{array}$ \\
\hline Sekutu setia & $\begin{array}{l}\text { Persepsi ancaman; kemampuan } \\
\text { lemah; kebijakan tradisional; } \\
\text { kesesuaian ideologis }\end{array}$ \\
\hline Contoh & Sumber tidak terungkap \\
\hline $\begin{array}{l}\text { Pihak yang } \\
\text { dilindungi }\end{array}$ & $\begin{array}{l}\text { Persepsi ancaman; kemampuan } \\
\text { lemah }\end{array}$ \\
\hline & Sumber: Holsti, 1988 \\
\hline
\end{tabular}

\section{PEMBAHASAN}

\section{SUMBER KONSEPSI PERAN NASIONAL}

Pembahasan penting selanjutnya adalah mengenai sumber konsepsi peran nasional. Sikap sebuah negara dalam politik internasional telah menjadi pembahasan para pengamat sejak era kerajaan. Sebagai contoh, peneliti hubungan antar negara di Tiongkok selama dinasti Chou dan di India selama periode Chandragupta telah mengidentifikasi mengenai 


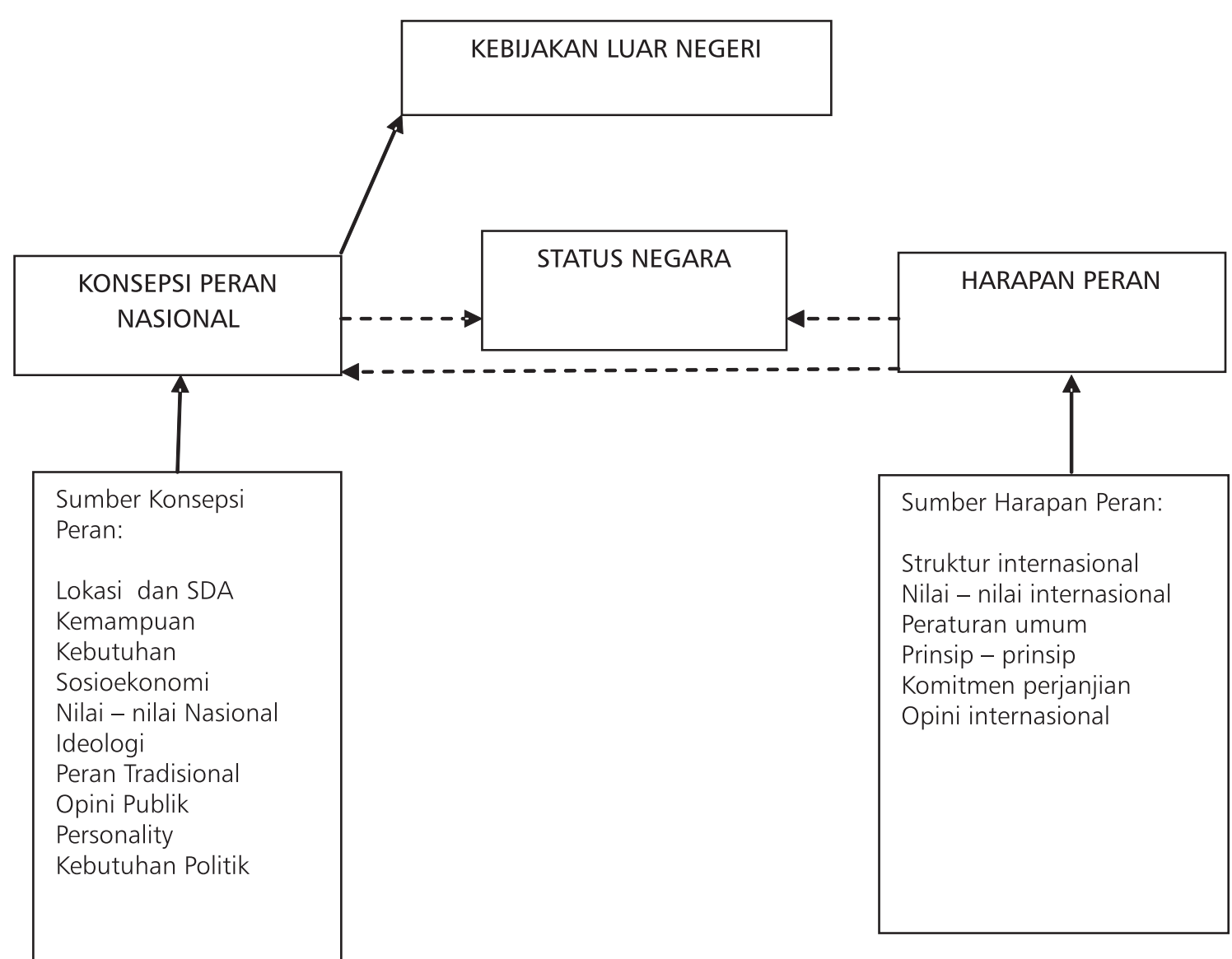

Sumber: Holsti, 1970

Keterangan:

--------- : menunjukkan berpengaruh secara langsung

-. - . - . - . :menunjukkan tidak berpengaruh secara langsung

Gambar1

Konsepsi Peran Nasional dan Kebijakan Luar Negeri

orientasi politik luar negeri kerajaan. Dalam

Arthasastra, Kautilya menggambarkan enam tipe kebijakan luar negeri, yaitu accomodation, hostility, indifference, attack, protection, dan double policy. Kautilya juga mengidentifikasi enam kategori peran nasional yang dengan spesifik menyebutkan sumber peran yang dihubungkan dengan karakteristik internal sebuah negara (Holsti, 1970).

Kesimpulan yang didapat oleh Kautilya adalah sumber utama peran nasional sebuah negara adalah status raja atau penguasa. Raja yang inferior biasanya lebih memiliki konsepsi accomodation atau protection atau dapat pula berubah menjadi double policy. Sedangkan kerajaan yang superior memiliki konsepsi peran hostility atau attack (Holsti, 1970: 248).

Dengan demikian, penelitian penting selanjutnya bagi pengkaji $\mathrm{HI}$ adalah sumber - sumber politik luar negeri. Dalam tipologi konsepsi peran nasional yang diungkapkannya, Holsti mengemukakan secara spesifik beberapa konsepsi peran yang dapat diidentifikasi sumber konsepsinya. Secara sederhana, sumber konsepsi tersebut dapat dilihat dalam tabel 1. 
Holsti (1970) telah menyebutkan beberapa sumber dari konsepsi peran sebuah negara. Dari berbagai sumber konsepsi peran, Holsti menyebutkan salah satu sumber yang sering menjadi acuan yaitu geografis yang merujuk pada letak dan struktur geografis. Geografis sebuah negara membuat pemimpin memiliki persepsi atas wilayahnya. Persepsi inilah yang dibawa dalam pembuatan kebijakan luar negeri.

Paige Tan (2007) menyatakan sumber politik luar negeri sebuah negara adalah menjaga integritas wilayah kekuasannya. Dalam konteks Indonesia, jumlah penduduk yang besar yang dipisahkan oleh struktur geografis kepulauan membuat Indonesia memberikan perhatian besar terhadap laut. Indonesia telah mempelajari bagaimana instabilitas politik yang muncul karena situasi ini yang muncul sejak masa penjajahan. Oleh karena itu, sejak awal pembentukan negara, pemimpin Indonesia memberikan perhatian khusus terhadap persoalan di Laut (Tan, 2007: 169).

Sependapat dengan Tan, Connie Bakrie menyebut struktur geografis Indonesia berdampak pada pandangan Indonesia dalam isu keamanan maritim. Indonesia memiliki posisi "supra strategis" dengan menjadi jalur pelayaran perdagangan internasional yang menghubungkan Asia Selatan, Asia Timur dan Asia Tenggara. Dengan demikian, arsitektur keamanan regional yang dibentuk di kawasan tidak dapat sukses tanpa dukungan Indonesia. Dalam tulisannya, Bakrie menyatakan:

"Indonesia should maintain its geographical suprastrategic position, particularly its strategic maritime areas. This is because Indonesia is the largest maritime state in ASEAN and its SLOCs (Malacca Strait, Lombok Strait, Moluccas and Wetar Strait) have been central to the ASEAN and the world. Meanwhile, regional maritime security - as the most important aspect of ASEAN Plus security architecture - can no longer be left entirely to Indonesia, ASEAN, and other regional bodies, because in the end it needs a strategy which may include collective maritime security" (Bakri, 2011: 3).

Pendapat para pengamat seperti Tan (2007) dan Bakrie (2011) juga juga tercermin dalam pandangan diplomat Indonesia. Sebagai contoh Indonesia, Mantan Menlu Marty Natalegawa, mengajukan usulan dibentuknya Indo-Pasifik dalam diskusi di CSIS, Washington tahun 2013. Marty Natalegawa memberikan ceramah mengenai bagaimana Indonesia memandang Indo-Pasifik. Dalam pandangannya, Indonesia berada diantara samudra India dan Samudra Pasifik, oleh karena itu Indonesia ingin menjadi penghubung bagi kedua samudra dengan cara memberi dukungan jalur tersebut sebagai jalur perdagangan dunia. Dalam kata - kata Marty Natalegawa:

"In terms of geography, it refers to an important triangular spanning two oceans, the Pacific and Indian Oceans, bounded by Japan in the north, Australia in the south-east and India in the south-west, notably with Indonesia at its center. Thus as a result, in this largest archipelagic state in the world, amidst its archipelagic waters, are found some of the most strategic sea lanes in the world: connecting the Indian and Pacific Oceans. Serving as highways for the movement of global trade, as well as of people and the associated ideas and cultural expressions they bring forth" (Natalegawa, 2013).

Atas kesadaran letak geografis Indonesia dalam jalur perdagangan dunia, Indonesia mendukung jalur perairan tersebut sebagai jalur perdagangan internasional yang menyokong pertumbuhan dunia. Selanjutnya, Indonesia tidak menutup mata dengan adanya beberapa potensi konflik yang muncul di kawasan seperti sengketa Laut Tiongkok Selatan (LTS) dan Laut Tiongkok Timur yang kemungkinan akan "mengganggu" jalur perdagangan dunia tersebut. Oleh karena itu, Indonesia harus memiliki pandangan dan sikap yang jelas dalam konflik di kawasan (Natalegawa, 2013).

Indonesia memandang persoalan legalitas 9 garis putus - putus berbentuk $U$ atau seringkali disebut $U$ Line dan 9 dash line yang merupakan klaim Tiongkok atas wilayah LTS masih menjadi perdebatan. Tiongkok belum memberikan penjelasan mengenai apakah garis tersebut merupakan garis teritorial atau garis kontinental atau garis zona ekonomi. Ketidak jelasan status garis itu membuat Indonesia "memilih" untuk 
tidak ikut mempersengketakan status wilayah di LTS. Indonesia pernah menanyakan kepada Tiongkok terkait dengan zona ekonomi Indonesia di perairan Natuna yang berbatasan dengan Vietnam dan Malaysia dimana wilayah ini termasuk bertabrakan dengan garis $U$ line yang dirilis Tiongkok. Tiongkok menjawab apa yang dilakukan Indonesia duah benar jika diukur dari Natuna, jadi Indonesia tidak memiliki perselisihan perbatasan dengan Tiongkok. Ketika Indonesia membuat kesepakatan dengan Vietnam berkaitan dengan zona ekonomi di wilayah perairan Natuna, ternyata Tiongkok tidak mempermasalahkan hal ini (Djalal, 2015, wawancara; Djumala, 2015, wawancara). Struktur geografis membuat politik luar negeri Indonesia mencurahkan perhatian besar terhadap persoalan kelautan di Asia Tenggara seperti yang tercermin dari pembentukan ASEAN Maritime Forum (AMF). Dalam Bali Concord II yang diselenggarakan pada 7 Oktober 2003, negara - negara anggota ASEAN menegaskan pentingnya pembahasan mengenai isu maritim sebagai bagian dari pembahasan mengenai ASEAN. Setelah melihat tumbuhnya kesadaran negara anggota ASEAN yang terletak dalam jalur laut perdagangan internasional, maka Indonesia mengusulkan pembentukan AMF pada ASEAN Security Community Plan of Action Coordinating Conference di sekretariat ASEAN pada tahun 2006. Kiprah Indonesia dilanjutkan dengan mengajukan konsep AMF dalam pertemuan pemimpin senior ASEAN di Singapura tahun 2008. Hasilnya adalah munculnya kesepakatan membentuk AMF dalam Pertemuan ASEAN ke-14 di Vietnam, 1 Maret 2009.Piagam ASEAN yang mulai berlaku pada 15 Desember 2008 juga antara lain menggarisbawahi kebutuhan untuk memastikan sentralitas ASEAN, khususnya dalam mengembangkan pemahaman dan pendekatan yang sama secara komprehensif terhadap isu-isu kelautan. Kemudian pada tanggal 28-29 Juli 2010 di Surabaya, forum tersebut secara resmi dibuka oleh Wakil Menteri Luar Negeri Republik Indonesia. Pertemuan ini membahas beberapa poin, yaitu (1) masalah keamanan maritim perlu ditangani, (2) menjajaki kerjasama operasional yang dapat dikembangkan secara konkrit dan (3) mengidentifikasi kerjasama di masa depan.

Di Era Pemerintahan Joko Widodo, pertimbangan politik luar negeri yang bersumber dari struktur dan letak geografis Indonesiamasih merupakan sumber politik luar negeri Indonesia. Menlu Retno Marsudi dalam Pernyataan Pers Tahunan Menteri (PPTM) 2015 menyatakan, "Diplomasi perbatasan akan lebih ditingkatkan pada tahun 2015. Khusus untuk penyelesaian batas maritim, Indonesia telah menyusun roadmap perundingan perbatasan" (Marsudi, 2015).

\section{DEKLARASI DJUANDA: DIPLOMASI NEGARA KEPULAUAN}

Penguasaan atas laut diatur berdasarkan konsepsi hukum.Hukum Laut Rhodia merupakan awal dari konsepsi hukum yang diterima oleh semua negara di tepi Laut Tengah.Hukum Laut Rhodia diterapkan pada abad ke-2 sebelum Masehi dan diadopsi oleh Romawi yang menguasai seluruh Laut Tengah pada abad ke-7.Konsep hukum yang diterapkan pada waktu itu adalah Laut merupakan milik bersama masyarakat dunia, oleh karena itu tidak ada satupun negara yang dapat memilikinya.Konsep hukum ini berhasil menjaga Laut Tengah dari gangguan bajak laut dan aman bagi negara sekitarnya.

Konsep hukum di atas dapat berjalan karena bangsa Romawi melindungi negara sekitar dan secara de facto Romawi lah yang menguasai Laut Tengah.Namun, runtuhnya Romawi pada abad pertengahan membuat negara - negara di tepi Laut Tengah menuntut bagiannya.Tuntutan mereka tersebut kemudian memunculkan pemikiran bahwa sebenarnya laut tidak dapat dimiliki bersama.Para ahli Hukum Romawi pada waktu itu seperti Bartolus dan Baldus mengemukakan sebuah teori yang isinya membagi wilayah laut menjadi dua, yaitu laut yang berada di bawah kekuasaan bangsa pantai dan laut lepas yanng bebas dari kekuasaan dan kedaulatan siapapun (Dam, 2010: 12-13).

Salah satu prinsip yang paling tua dan paling diakui dalam mengatur perairan internasional adalah prinsip yang diutarakan oleh Hugo Grotius dalam bagian "de mare liberum". Dia menyatakan bahwa perairan merupakan wilayah yang dapat digunakan oleh 
siapapun untuk kepentingan komersil dan menolak kepemilikan eksklusif terhadap laut. Namun, prinsip ini menghadirkan persoalan tersendiri bagi negara pantai dan negara kepulauan dimana kedaulatan negara dalam mengelola kekayaan laut seperti perikanan dan keamanan nasional terancam.

Sampai berakhirnya Perang Dunia II, hukum laut yang berlaku di masyarakat internasional adalah hukum kebiasaan (customary law). Dalam hukum kebiasaan ini, ada tiga wilayah laut yang diakui yaitu (1) laut teritorial dimana setiap negara pantai memiliki kedualatan penuh sejuah 3 mil dari garis air surut di sepanjang pantai di setiap daratan yang dimiliki, (2) jalur tambahan selebar laut teritorial, dimana negara pantai memiliki hak berdaulat untuk melakukan pengejaran apabila terjadi pelanggaran di laut teritorial, dan (3) selebihnya dianggap sebagai laut bebas dimana "mere liberum" diberlakukan. Bagi Indonesia, hukum kebiasaan ini tetap menimbulkan persoalan tersendiri, oleh karena itu para pemimpin bangsa mematangkan konsep wilayah Indonesia yang meliputi lautan dan daratan.

Dengan meningkatnya jumlah negara merdeka paska PD II, pandangan negara terhadap laut mulai berubah. Negara - negara memandang laut memiliki arti strategis dalam keamanan nasional. Merespon perkembangan ini, PBB menyelenggarakan Konferensi Hukum Laut (KHL) I di Jenewa pada tahun 1958.

Wilayah Indonesia yang terdiri dari ribuan pulau membuat Indonesia menolak prinsip Hugo Grotius. Indonesia menyatakan sikap resmi sebelum pelaksanaan KHL I, sekaligus dalam posisinya sebagai negara kepulauan, pada tanggal 13 Desember 1957 yang dikenal sebagai deklarasi Djuanda. Dalam deklarasi itu, Indonesia menyatakan bahwa seluruh perairan yang terletak di sekitar, di antara, dan yang menghubungkan pulau - pulau Indonesia adalah kedaulatan mutlak Indonesia. Kemudian, deklarasi tersebut merinci lebar laut teritorial adalah $12 \mathrm{mil}$ yang diuukur sejajar dengan garis dasar lurus yang menghubungkan titik - titik terluar yang terletak pada pulau - pulau terluar milik Indonesia. Selanjutnya, Indonesia menyatakan wilayah laut yang berada di sebelah dalam garis dasar dianggap sebagai perairan pedalaman.

Deklarasi Djuanda dikeluarkan oleh pemerintah Indonesia berdasarkan empat pertimbangan penting. Pertama, bentuk geografi Indonesia merupakan kepulauan sehingga memiliki sifat dan corak yang berbeda dengan negara lain, oleh karena itu diperlukan pengaturan secara khusus. Kedua, pemerintah menganggap wilayah lautan dan daratan merupakan sebuah kesatuan yang tidak dapat dipisah - pisah. Ketiga, penetapan batas - batas teritorial yang diwarisi dari pemerintah Belanda sebagaimana yang termaktub dalam Territorial Zee en Maritime Kringen Ordonnatie 1939 pasal 1 ayat (1), yaitu selebar 3 mil diukur dari garis rendah di pantai dan setiap pulau, tidak sesuai lagi denhgan kepentingan keselamatan dan keamanan negara Indonesia. Keempat, setiap negara yang berdaulat berhak dan berkewajiban mengambil tindakan yang dipandang perlu untuk melindungi keutuhan dan keselamatan negaranya (Gunadirja et al, 1998: 405).

Dengan demikian, sejak tahun 1957, Indonesia sudah mulai menegaskan Wawasan Nusantara untuk menyatukan wilayah Indonesia yang terdiri dari beriburibu pulau.Deklarasi tersebut muncul karena pemerintah Indonesia merasa wilayah kepulauan seperti Indonesia membutuhkan aturan tersendiri. Hukum laut warisan kolonial yang membatasi laut teritorial selebar 3 mil dari garis air rendah dianggap tidak sesuai dengan keamanan Indonesia. Berbahayanya hukum laut kolonial dapat dilihat dalam kasus pembebasan Irian Barat.Dalam kasus tersebut, sah-sah saja jika kapal perang Belanda mondar-mandir di Laut Jawa.

Kemudian, sebagai respon peristiwa pembebasan Irian Barat, Menteri Chaerul Saleh meminta Mochtar Kusumaatmadja sebagai penasehat untuk membuat konsep agar Laut Jawa bisa dijadikan laut pedalaman. Dengan demikian, lahirlah konsep negara kepulauan dalam Deklarasi Djuanda. Dalam konsep tersebut didasarkan prinsip Wawasan Nusantara yang menegaskan bahwa persatuan dan kesatuan bangsa harus diikuti dengan kesatuan geografis yang kokoh. 
Deklarasi Djuanda menyulut protes dari beberapa negara besar yang selama ini menggunakan laut Indonesia. Namun, pemerintah Indonesia tetap mempertahankan deklarasi ini yang ditunjukkan dengan menerbitkan UU No. 4 Prp Tahun 1960 dan Peraturan Pemerintah No. 8 Tahun 1962 tentang Lalu Lintas Damai Kendaraan Asing. Pemerintah juga mengeluarkan Pengumuman mengenai landas Kontinen pada 17 Februari 1969 yang dikukuhkan melalui UU No. 1 Tahun 1973 tentang Landas Kontinen.

Deklarasi Djuanda terbukti menambah luas wilayah Indonesia meningkat tajam. Pada saat Indonesia merdeka pada tanggal 17 Agustus 1945, Indonesia memiliki wilayah laut hanya 3 mil dari garis pantai masing - masing pulau atau hanya sekitar 100.0000 km2. Ketika Deklarasi Djuanda pada 13 Desember 1957, luas wilayah laut Indonesia diukur menjadi 12 mil dari pulau sehingga luas wilayah laut Indonesia mencapai 3,000,000 km2 atau naik 30 kali lipat. Havas Oegroseno (2012: 31) menyebut Deklarasi Djuanda sebagai awal dari lahirnya border diplomacy untuk mempertahankan dan mempromosikan prinsip - prinsio negara kepulauan. Diplomasi dilakukan dengan melakukan negosisasi dengan negara - negara tetangga seperti India, Malaysia, Singapura, Papua Nugini dan Australia untuk mempertahankan wilayah Indonesia.

Konsep negara kepulauan melalui Deklarasi Djuanda telah membawa perubahan persepsi bangsa Indonesia terhadap laut dimana laut bukan lagi menjadi pemisah tetapi merupakan penghubung dan pemersatu wilayah kedaulatan Indonesia. Deklarasi Djuanda memberikan keuntungan secara ekonomi dimana Indonesia berhak mengelola kekayaan yang ada di seluruh perairan dalam. Dalam konteks militer, Indonesia memiliki kedaulatan atas selat dan perairan dalam sehingga kapal asing yang melalui perairan Indonesia dapat dipantau oleh pemerintah.Perhatian Indonesia terhadap hukum laut pun meningkat sehingga pemerintah membentuk Dewan Maritim untuk mengeksplorasi pemahaman mengenai hukum laut dan diplomasi.
Langkah pertama yang dilakukan pemerintah sebagai negara kepulauan adalah mensosialisasikan mengenai konsep negara kepulauan. Pada Konferensi Hukum Laut (KHL) II tahun 1960 di Jenewa, Indonesia menyadari konferensi ini tidak mampu mengakomodasi kepentingan Indonesia sesuai dengan Deklarasi Djuanda. Oleh karena itu, pemerintah menetapkan berbagai peraturan untuk melindungi wilayah laut. Pada tahun 1963 muncul Keppres No. 103 yang menyebutkan bahwa seluruh wilayah perairan Indonesia merupakan kesatuan lingkaran maritim yang tunduk pada hukum Indonesia.Pada tahun 1969 pemerintah Indonesia mengumumkan mengenai Landas Kontinen, yang menegaskan bahwa segala sumber kekayaan alam dalam landas kontinen Indonesia eksklusif milik negara Indonesia.

Karena konsep negara kepulauan Indonesia belum bisa diterima dalam Konferensi Hukum Laut II tahun 1960, Indonesia melalui Panitia Landas Kontinen dari Departemen Pertambangan mulai mengadakan persetujuan-persetujuan secara bilateral dengan Malaysia, Thailand, Australia, India, Singapura, maupun Papua Nugini. Persetujuan-persetujuan tersebut terutama menyangkut kekayaan minyak dan gas, serta garis batas wilayah dengan negara-negara tetangga.

Diplomasi dalam hukum laut dilanjutkan di era Orde Baru. Beberapa persoalan menyangkut laut yang muncul pada waktu itu seperti pencemaran laut yang dikarenakan kecelakaan kapal tanker Torrey Canyon tahun 1967 di dekat pantai Prancis dan Inggris, kemudian munculnya tuntutan dari negara - negara Afrika yang menuntut hak mereka atas kekayaan laut dan semakin tingginya pengetahuan untuk mengeksplorasi kekayaan laut membuat pengaturan akan laut semakin penting. Oleh karena itulah PBB mengagendakan diadakannya KHL III pada tahun 1973. Untuk menghadapi KHL III ini, Indonesia membentuk Penitia Koordinasi Masalah Wilayah Nasional (Pankorwilnas) dengan Keppres No.36 tahun 1971 dan menempatkannya di bawah pimpinan Asisten Operasi Hankam (Gunadirja et al, 1998: 411412).

Diplomasi Indonesia dalam mempertahankan 
wilayah laut dilakukan pula dalam beberapa pertemuan internasional seperti Indonesia bersama dengan beberapa negara kepulauan lain seperti Filipina dan Fiji dengan bersama - sama merumuskan prinsip pokok konsepsi negara kepulauan melalui pertemuan di Manila tahun 1971. Prinsip pokok yang disepakati ini kemudian dibawa Indonesia dalam sidang Asian African Legal Consultative Committee (AALCC) di Kolombo pada tahun 1971. Dalam sidang tersebut, Indonesia menyatakan kembali prinsip pokok yang mendasari pemikiran Indonesia dalam memandang wilayahnya. Sosialisasi yang dilakukan Indonesia mendapatkan respon beragam. Pada waktu itu ada beberapa negara yang mendukung, yang kemudian negara memberikan dikukang dalam KHL III. Namun, ada pula yang mempertanyakan mengenai dasar pemikiran Indonesia.

Selain melalui AALCC, Indonesia juga mensosialisasikan prinsip negara kepulauan kepadaUni Afrika pada tahun 1972 di Addis Ababa dan tahun 1973 di Mogadishu. Indonesia juga meminta dukungan kepada negara berkembang dalam pertemuan di Nairobi, Kenya, pada tahun 1974.

Dengan gencar melakukan diplomasi, Wawasan Nusantara menjadi isu penting yang akhirnya dibahas dalam Konferensi Hukum Laut III. KHL III sendiri berlangsung cukup lama yaitu dari tahun 1973 sampai tahun 1982. Hal ini dikarenakan oleh adanya masalahmasalah yang masih muncul, yaitu masalah definisi dari Konsepsi Nusantara, hak-hak negara tetangga yang terkait, pemakaian status "archipelago" atau "archipelagic state", lalu lintas kendaraan air maupun pesawat asing yang melalui perairan dengan konsep Kesatuan Nusantara, serta masalah hak-hak negara Nusantara untuk memperoleh Laut Pedalaman, Laut Teritorial, Zona Ekonomi Eksklusif, Zona Tambahan, dan batas Landas Kontinen.

Setelah pembahasan panjang dan diplomasi Indonesia yang tiada henti, dalam pemungutan suara pada tanggal 30 April 1982, pada akhirnya, Indonesia berhasil mendapatkan kesepakatan mengenai negara kepulauan melalui KHL III PBB tahun 1982 yang ditandatangani di Montenegro Bay, Jamaica. Dalam konvensi tersebut, konsep negara kepulauan yang diamanatkan Deklarasi Djuanda dapat diterima sebagai bagian integral dari Konvensi Hukum Laut PBB.Dalam forum tersebut negara yang setuju berjumlah 130 negara, 17 negara abstain, dan 4 negara menolak (Amerika Serikat, Israel, Venezuela, Peru). ${ }^{1}$ Pada hari pertama penandatanganan pada 10 Desember 1982, 119 negara menandatangani konvensi, termasuk 5 negara ASEAN.

Peranan Indonesia dalam Hukum Laut Internasional 1982 membuat Indonesia menjadi negara yang memiliki perhatian besar dalam persoalan laut. Indonesia aktif dalam upaya implementasu Konvensi Hukum Laut pada tingkat internasional seperti keikutsertaan Indonesia pada sidang Preparatory Commision Hukum laut dan Kerja sama Kelautan Samudera Hindia Indian Ocean Marine Affairs Cooperation (IOMAC). Indonesia juga aktif dalam pertemuan "Indian Ocean Rim Initiative" dan pada Maret 1997 telah dibentuk "Indian Ocean Rim Association for Regional Cooperation" (IOR-ARC).Indonesia juga memandang penting masalah Hukum Laut. Oleh karena itu, Pemerintah mengangkat Duta Besar Keliling untuk Hukum Laut yang dipercayakan kepada Hasyim Djalal (Gunadirja, 1998: 445-450).

Konvensi Hukum Laut 1982 sudah mulai berlaku sejak tanggal 16 November 1994, yaitu satu tahun setelah jumlah negara yang meratifikasi konvensi mencapai 60 negara. Namun, dari 60 negara tersebut tidak ada satu pun negara maju yang meratifikasi. Bahkan, AS menjadi satu - satunya negara yang menolak keras.

Dengan meningkatnya kesadaran masyarakat dunia akan pentingnya laut, Indonesia menjalin bermacam kerja sama untuk menjaga kedaualatan sebagai negara kepulauan sekaligus aktif dalam pergaulan masyarakat internasional. wilayah Indonesia yang merupakan jalur perdagangan dunia membuat Indonesia harus melakukan langkah - langkah pengamanan di laut yang merupakan wilayah kekuasaan Indonesia. Krusialnya peran laut dalam perdagangan dunia juga dihadapkan pada bermacam persoalan yang menyelimuti seperti terorisme dan pembajakan di laut. Berbagai persoalan 
ini disikapi Indonesia dengan melakukan kerja sama dalam mengelola laut.

Indonesia memiki perhatian yang besar dalam persoalan samudra hindia. Dalam pernyataan Pers Tahunan akhir tahun 1995, Menlu Ali Alatas menyatakan Indonesia akan mengikuti perkembangan kerja sama di kawasab Sanudra Hindia karena Indonesia berada di Samudra Hindia dan perkembangan perkembagan itu dapat berpengaruh terhadap Pembangunan Jangka Panjang Indonesia (Gunadirja et al, 1998:797).

Pernyataan Ali Alatas di atas merujuk pada perkembangan situasi di Samudra Hindia. Majelis Umun PBB oada tahun 1971 tekah menerima suatu deklarasi yang menyatakan kawasan samudra Hindia merupakan kawasan damai. Untuk itu, PBB membentuk Komite Ad-Hoc Samudera India yang bertugas untuk mempersiapkan konferensi tentang samudera India. Dalam perkembangannya, beberapa negara seperti AmerikaSerikat tidak menghendaki adanya zona damai di Samudera Hindia karena akan mengganggu kepentingan strategisnya seperti eksistensi pangkalan Angkatan Laut AS di Diego Garcia.

Indonesia memiliki sikap jelas dalam menanggapi situasi di atas dengan mengembangkan kerja sana dengan negara - negara yang memiliki pantau Samudera Hindia seperti Australia dan beberapa negara dinkawasan Afrika. Indonesia dengan beberapa negara berupaya mengembangkan "Indian Ocean Marine Aafairs Cooperation" atau (IOMAC). Hasil dari IOMAC ini salah satunya adalah Arusha Charter.

Pada tahun 1999, Presiden Abdurrahman Wahid mencanangkan tanggal 13 Desember sebagai Hari Nusantara. Penetapan hari ini dipertegas oleh Presiden Megawati dengan menerbitkan Keputusan Presiden RI Nomor 126 Tahun 2001 tentang Hari Nusantara, sehingga tanggal 13 Desember resmi menjadi hari perayaan nasional tidak libur.

\section{DIPLOMASI PERBATASAN: PEKERJAAN RUMAH YANG BELUM TUNTAS}

Konsepsi peran Indonesia yang bersumber dari letak dan struktur geografis menjelaskan mengenai bagaimana perilaku Indonesia dalam politik luar negeri. Pentingnya pembahasan mengenai letak geografis dan status negara kepulauan mengacu pada beberapa fakta yang menjelaskan perilaku Indonesia dalam politik luar negeri. Pertama, Indonesia melakukan berbagai kerja sama dalam bidang maritim bukan dengan negara yang memiliki ideologi yang sama saja, namun melakukannya dengan berbagai negara seperti AS, Rusia, Tiongkok dan Uni Eropa. Kedua, dalam menjalankan kerja sama luar negeri di bidang maritim, Indonesia tidak terpengaruh dengan ASEAN. Sebagai contoh Indonesia tidak tergabung dalam The Regional Cooperation Agreement on Combating Piracy and Armed Robbery against Ships in Asia (ReCAAP) yang ditandatangani pada 11 November 2004 antara negara - negara anggota ASEAN (kecuali Indonesia dan Malaysia) dan 11 negara di luar kawasan. Ketiga, status sebagai negara kepulauan telah diperjuangkan sejak era Soekarno hingga dituangkan dalam UNCLOS 1982. Konsekuensi dari UNCLOS, Indonesia harus menyepakati garis ordinat titik terluar dengan negara tetangga.

Indonesia melakukan upaya preventif untuk menjaga integritas wilayahnya. Setelah berhasil memperjuangkan diplomasi sebagai negara kepulauan melalui UNCLOS 1982, Indonesia menindaklanjuti dengan UU Nomor 17 tahun 1985 tentang pengesahan UNCLOS. Pemerintah Indonesia juga mengeluarkan UU Nomor 6 tahun 1996 tentang Perairan Indonesia. UU ini dibuat dengan maksud untuk mempertegas batasan terluar dan yuridiksi Indonesia di laut. Selanjutnya UU Nomor 6 tahun 1996 dilengkapi dengan PP Nomor 61 tahun 1998 tentang Daftar Koordinat Geografis Titik - titik pangkal Kepulauan Indonesia di sekitar Kepulauan Natuna yang kemudian dicabut dan diganti dengan PP Nomor 38 tahun 2002 tentang Daftar Koordinat Geografis Titik - titik Pangkal Kepulauan Indonesia. Berbagai upaya Indonesia ini merupakan upaya preventif untuk legalitas wilayah Indonesia.

Namun demikian, hingga saat ini terdapat beberapa permasalahan perbatasan antara Indonesia dengan negara tetangga yang masih belum diselesaikan secara 
tuntas. Permasalahan perbatasan tersebut tidak hanya menyangkut batas fisik yang telah disepakati namun juga menyangkut cara hidup masyarakat di daerah tersebut, misalnya para nelayan tradisional atau kegiatan lain di sekitar wilayah perbatasan. Sebagai contoh perbatasan antara Indonesia - Malaysia. Kedua negara telah memiliki kesepakatan batas negara antara lain Kesepakatan garis batas Landas Kontinen di Selat Malaka dan Laut Natuna berdasarkan Persetujuan antara Pemerintah Republik Indonesia dan Pemerintah Kerajaan Malaysia tentang penetapan garis batas landas kontinen antara kedua Negara (Agreement Between Government of the Republic Indonesia and Government Malaysia relating to the delimitation of the continental shelves between the two countries) pada tanggal 27 Oktober 1969. Kemudian, perjanjian ini diratifikasi dengan Keppres Nomor 89 Tahun 1969 dan Penetapan Garis Batas Laut Wilayah RI - Malaysia di Selat Malaka pada tanggal 17 Maret 1970 di Jakarta. Selanjutnya Kepres diperkuat dengan Undang-undang Nomor 2 Tahun 1971 tanggal 10 Maret 1971. Namun untuk garis batas ZEE (Zona Ekonomi Eksklusif) di Selat Malaka dan Laut Tiongkok Selatan antara kedua negara belum ada kesepakatan.

Batas laut teritorial Malaysia di Selat Singapura terdapat masalah yaitu di sebelah Timur Selat Singapura, yaitu kepemilikan Karang Horsburgh (Batu Puteh) antara Malaysia dan Singapura, terletak di tengah antara Pulau Bintan dengan Johor Timur, yang jaraknya kurang lebih 11 mil. Jika Karang Horsburg ini menjadi milik Malaysia maka jarak antara karang tersebut dengan Pulau Bintan kurang lebih 3,3 mil dari Pulau Bintan.

Perbatasan Indonesia dengan Malaysia di Kalimatan Timur (perairan Pulau Sebatik dan sekitarnya) dan Perairan Selat Malaka bagian Selatan hingga saat ini masih dalam proses perundingan. Pada segmen di Laut Sulawesi, Indonesia menghendaki perundingan batas laut teritorial dahulu baru kemudian merundingkan ZEE dan Landas Kontinen. Pihak Malaysia berpendapat perundingan batas maritim harus dilakukan dalam satu paket, yaitu menentukan batas laut teritorial, Zona Tambahan, ZEE dan Landas
Kontinen. Pada segmen Selat Malaka bagian Selatan RI dan Malaysia masih sebatas tukar menukar peta illustrasi batas laut teritorial kedua negara.

Contoh lainnya adalah perbatasan RI - Thailand. Negara Indonesia dengan Thailand telah mengadakan perjanjian landas kontinen di Bangkok pada tanggal 17 Desember 1971, perjanjian tersebut telah diratifikasi dengan Keppres Nomor 21 Tahun 1972. Perjanjian perbatasan tersebut merupakan batas landas kontinen di Utara Selat Malaka dan Laut Andaman.

Selain itu telah dilaksanakan perjanjian batas landas kontinen antara tiga negara yaitu Indonesia, Thailand dan Malaysia yang diadakan di Kuala Lumpur pada tanggal 21 Desember 1971. Perjanjian ini telah diratifikasi dengan Keppres Nomor 20 Tahun 1972. Meskipun demikian, perbatasan antara Indonesia dengan Thailand belum diselesaikan khususnya perjanjian ZEE.

Secara lengkap, Hari Bowo (2012) mengulas Indonesia masih memiliki persolan perbatasan dengan India, Singapura, Vietnam, Filipina, Republik Palau, Papua Nugini, Australiaa, dan Timur Leste.Belum ditetapkannya perbatasan maritim dengan negara tetangga mengakibatkan pelaksanaan penegakan kedaulatan dan hukum di daerah perbatasan mengalami kendala. Khususnya dalam melaksanakan patroli penegakan kedaulatan dan hukum di daerah perbatasan KRI mendapat kesulitan dalam menentukan sampai sejauh mana patroli yang harus dilaksanakan. Kondisi ini untuk menghindari adanya pelanggaran wilayah yang kemungkinan dapat terjadi. Selain itu jika terjadi insiden ataupun pelanggaran hukum akan mengalami kesulitan hukum negara mana yang akan diterapkan dan jenis pelanggaran atau tindak pidana apa yang dapat dikenakan kepada para pelanggar tersebut.

\section{KESIMPULAN}

Letak strategis Indonesia telah menjadi sumber politik luar negeri sejak awal kemerdekaan. Di Era pemerintahan Soekarno, Indonesia telah menggunakan letak strategis Indonesia dalam perdagangan dunia sebagai pendorong untuk menetapkan batas wilayah 
melalui konsep negara kepulauan yang tertuang dalam Deklarasi Djuanda. Kemudian, perjuangan Indonesia diakui sebagai negara kepulauan mendapatkan legalitas di era pemerintahan Soeharto dalam Konvensi Hukum Laut Internasional. Sementara itu, letak geografis Indonesia menjadi sumber politik luar negeri di Era Reformasi dengan memberikan perhatian pada diplomasi perbatasan dan menyikapi isu - isu internasional berkaitan dengan kelautan seperti sengketa Laut Tiongkok Selatan. Secara ringkas, penelitian ini menekankan Politik Luar Negeri Indonesia di masa yang akan datang akan terus mempertimbangkan letak geografis Indonesia sebagai sumber politik luar negeri.

\section{CATATAN KAKI}

Penolakan Amerika Serikat pada masa Presiden Reagan adalah mengenai masalah penambangan mineral di dasar laut internasional yang menurut Amerika tidak sesuai dengan prinsip kapitalisme dan pasar bebas.

\section{REFERENSI}

Bakrie, Connie. 2011. "Deepening the ADMM Security Leg : Indonesia's Maritime Security and the Role of India \& Australia." This paper is presented at the Delhi Dialogue III - Beyond the First Twenty Years of India-ASEAN Engagement, Le Meridien Hotel, March 3-4, 2011, New Delhi. Dapat diakses melalui http://s3.amazonaws.com/ zanran_storage/www.delhidialogue.com/ContentPages/ 2474793323.pdf pada 25/1/2016

Dam, S. 2010. Politik kelautan. Jakarta: Bumi Aksara.

Gunadirja, et al. 1998.Sejarah Diplomasi Republik Indonesia dariMasa ke Masa: Periode 1960-1965 (Buku IVB), (Jakarta: Departemen Luar Negeri RI, 1996)

Hari, Bowo. 2012. Makalah Koorsahli Kasal Laksamana Muda TNI Hari Bowo, M.Sc. pada Seminar Nasional "Strategi Pengelolaan Wilayah Perbatasan Maritim Indonesia" yang diselenggarakan oleh Ikatan Mahasiswa Hubungan Internasional Universitas Paramadina Jakarta pada tanggal 26 November 2012

Holsti, K.J. 1988. Politik Internasional: Kerangka untuk Analisis terjemahan M. Tahir Azhary. Jakarta: Penerbit Erlangga

Holsti, K.J.1970. "National role Conceptions in the Study of Foreign Policy". International Studies Quarterly volume 14. Number 3 (Sept 1970).

Kahin, Audrey R \& Kahin, George McT. 1997.Subversi Sebagai Politik Luar Negeri; MenyingkapKeterlibatan CIA di Indonesia. Jakarta: Pustaka Utama Grafiti

Marsudi, Retno LP. 2015. Pernyataan Pers Tahunan 2015. Melalui unw.kemlu.go.id

Natalegawa, Marty. 2013. "AN INDONESIAN PERSPECTIVE ON THE INDO-PACIFIC". Pidato Marty Natalegawa di Konferensi yang diselenggarakan oleh CSIS Washington 16 Mei 2013 melalui http://
csis.org/files/attachments/130516_MartyNatalegawa_Speech.pdf yang diakses 12/5/2015

Oegroseno, Arif Havas. 2012. "Maritime Border Diplomacy: An Indonesian Lifeline". Di dalam Myron H. Nordquist, John Norton Moore.Maritime Diplomacy Border page 31-33. Leiden [etc.] : Nijhoff

Tan, Paige Johnson. 2007. "Navigating A Turbulent Ocean: Indonesia's Worldview and Foreign Policy". Asian Perspectives 2007.

Tayer, Charles A. 2011. "The Tyranny of Geography: Viatnemese Strategies to Constarain China in the South China Sea" . Contemporary Southeast Asia, 33(3): 348-369

Thies, Cameron G. 2002. "A Pragmatic Guide to Qualitative Historical Analysis in the Study if International Relations". International Studies Perspectives (2002) 3 : 351-372. 